\title{
Disparitas Kematian Maternal di Indonesia: Studi Ekologi dengan Analisis Spasial
}

\section{Disparity of Maternal Mortality in Indonesia: Ecological Study with Spatial Analysis}

\author{
Rahmah Hida Nurrizka ${ }^{*}$, Tri Yunis Miko Wahyono ${ }^{2}$ \\ ${ }^{1}$ Prodi Kesehatan Masyarakat, Universitas Pembangunan Nasional Veteran Jakarta \\ ${ }^{2}$ Departemen Epidemiologi, Fakultas Kesehatan Masyarakat, Universitas Indonesia \\ ('rh.nurrizka@gmail.com)
}

\begin{abstract}
ABSTRAK
Penelitian ini menganalisis disparitas kematian maternal di Indonesia dengan analisis spasial menggunakan faktor intermediet, seperti pelayanan kesehatan maternal, status reproduksi, sosial ekonomi dan demografi. Tujuan penelitian adalah menganalisis secara spasial disparitas kematian maternal, pengaruh dan risiko kematian maternal terhadap faktor intermediet, dan memberikan rekomendasi terhadap masalah kesehatan maternal di Indonesia. Penelitian menggunakan desain studi ekologi (studi agrerat), analisis spasial, bivariat, dan multivariat. Unit analisis penelitian adalah kabupaten/kota di seluruh Indonesia. Hasil penelitian menunjukkan terjadi disparitas kematian maternal yang diakibatkan kesenjangan faktor intermediet antara kabupaten/kota di Indonesia, dengan risiko kematian maternal tertinggi terjadi di wilayah Indonesia Timur. Faktor yang paling mempengaruhi kematian maternal adalah kepadatan penduduk dengan OR:0,283 (95\%CI:0,185-0,430) dan persalinan oleh tenaga kesehatan (PN) dengan OR:1,745 (95\%CI:1,081-2,815). Risiko kematian maternal tinggi terjadi pada kabupaten/ kota dengan cakupan kunjungan kehamilan keempat (K4) rendah, cakupan persalinan oleh tenaga kesehatan (PN) rendah, cakupan kunjungan nifas (KF) rendah, rata-rata jumlah anak tinggi, rata-rata lama sekolah wanita usia subur rendah, dan kemiskinan tinggi.
\end{abstract}

Kata kunci : Kematian maternal, faktor intermediet, analisis spasial

\section{ABSTRACT}

This study is an analyze disparity of maternal mortality in Indonesia with spatial analysis using intermediate factor such as maternal health service, reproduction status, socio economic and demography. This study aimed to spatially analyze disparity of maternal mortality, analyze the influence and risk of maternal mortality on intermediate factors, and provide recommendations on maternal health problems in Indonesia. This study using ecological study design (agrerat studies), spatial analysis, bivariate analysis, and multivariate analysis. Unit of analysis in this study is districts/cities in Indonesia. The results showed that disparity of maternal mortality caused by intermediate factor gap between districts/cities in Indonesia, with the highest risk of maternal mortality occurred in eastern Indonesia. The dominant variables related to maternal mortality, namely population density with OR:0,283 (95\% CI:0,185-0,430) and childbirth by skilled health personal with OR:1,745 (95\% CI:1,081-2,815). The high risk of maternal mortality occurred in districts/cities with low coverage of fourth pregnancy (K4), low birth attendance $(P N)$ coverage, low postpartum $(K F)$ coverage, average number of children, low average education, and high poverty.

Keywords : Maternal mortality, intermediates factors, spatial analysis 


\section{PENDAHULUAN}

Ancaman kematian maternal masih menjadi masalah utama di negara berkembang termasuk Indonesia. Berdasarkan data World Health Organization (WHO) sebanyak 830 wanita hamil dan melahirkan meninggal setiap harinya dan terbesar terjadi di negara berkembang, seperti negara di kawasan Afrika, Haiti, Guyana, Bolivia, Nepal, Myanmar, India dan Indonesia. ${ }^{1}$

Indonesia termasuk negara yang mengalami peningkatan angka kematian maternal. Berdasarkan Hasil Survei Demografi dan Kesehatan Indonesia (SDKI) tahun 2012 terjadi peningkatan ang-ka kematian maternal atau Angka Kematian Ibu (AKI) dari 228 per 100.000 kelahiran hidup pada tahun 2007 menjadi 359 per 100.000 kelahiran hidup. Angka tersebut jauh dari target MDGs tahun 2015 sebesar 102 per 100.000 kelahiran hidup pada $2015 .{ }^{2}$ Dari kondisi tersebut, perlu upaya keras dari pemerintah untuk mengatasi masalah kematian maternal agar target Sustainable Development Goals (SDGs) sebesar 70 per 100.000 kelahiran hidup pada 2030 bisa dicapai. ${ }^{3}$

Banyak faktor yang menyebabkan peningkatan angka kematian maternal di Indonesia Selain faktor penyebab langsung, seperti pendarahan, hipertensi, infeksi, partus lama, dan abortus, ${ }^{4}$ penyebab utama kematian maternal juga dipengaruhi oleh penyebab tidak langsung atau intermediet. Faktor intermediet diantaranya adalah faktor pelayanan kesehatan seperti pelayanan saat hamil, melahirkan, dan setelah melahirkan, ${ }^{5}$ faktor status reproduksi, ${ }^{6}$ faktor demografi seperti pendidikan dan kependudukan, ${ }^{7}$ dan faktor ekonomi seperti kemiskinan. ${ }^{8}$

Perbaikan faktor intermediet untuk menurunkan angka kematian maternal menjadi penting dilakukan. Namun, ini memerlukan multi-stakeholder untuk mengatasinya. Jika pelayanan kesehatan seperti pemeriksaan kehamilan (antenatal care/ANC) dan pelayanan persalinan dapat diperbaik baik secara akses maupun kualitas layanan maka kesehatan maternal bisa lebih terpantau dan dapat memitigasi dengan cepat masalah kematian maternal. ${ }^{9}$

Begitu juga aspek pendidikan. Ibu hamil yang memiliki pendidikan lebih tinggi memiliki adaptasi yang lebih baik dalam mengatasi masalah kesehatan saat kehamilan, persalinan, dan nifas.
Sedangkan ibu hamil yang tidak memiliki pengetahuan terkait persoalan kesehatan maternal sangat beresiko tinggi terhadap risiko kematian. ${ }^{10,11}$

Persoalan kemiskinan juga menjadi masalah dalam kematian maternal di Indonesia. Walaupun ada upaya pemerintah mengatasi persoalan kemiskinan, tetapi masalahnya adalah banyak program penanggulangan kemiskinan yang tidak terintegrasi dengan sektor kesehatan terutama kesehatan maternal. Hal ini bisa dilihat dari rendahnya akses kesehatan maternal pada kelompok miskin. Sehingga risiko kematian terhadap kelompok ini menjadi lebih tinggi. ${ }^{12,13}$

Selain faktor kemiskinan, faktor demografi juga memberikan dampak terhadap persoalan kematian maternal. Salah satu indikatornya adalah soal kependudukan, yaitu tingkat kepadatan penduduk. Tingkat kepadatan penduduk yang tinggi menyebabkan fertilitas tinggi, ketika kondisi layanan kesehatan masih belum terjangkau dengan baik dan jumlah anak yang banyak dan jaraknya rapat menjadikan risiko kematian maternal tinggi di daerah tersebut. ${ }^{14}$

Di Indonesia, penelitian terkait pengaruh faktor intermediet terhadap kematian maternal sudah banyak dilakukan. Namun, belum banyak melihat faktor ini secara spasial dan membandingkannya antar kabupaten/kota. Padahal, pendekatan spasial dan disparitas penting agar menemukan permasalahan yang terjadi antar daerah karena masing-masing daerah memiliki faktor penyebab berbeda dan intervensi penangganannya juga berbeda. ${ }^{15}$

Penelitian ini menganalisis disparitas kematian maternal di Indonesia dengan menggunakan data pada level kabupaten/kota dengan pendekatan ekologi (studi agrerat) dan spasial. Analisis spasial digunakan dengan melibatkan sejumlah fungsi hitungan dan evaluasi logika matematis berbasis data dan informasi spasial dalam rangka untuk mendapatkan ekstraksi, penilaian atau informasi terkait ruang dan wilayah. Dalam penelitian ini analisis spasial terdiri dari a body of technique, yang menganalisis hubungan antara ruang/wilayah dari kasus kematian maternal dengan variabel intermediet (faktor risiko) yang mempengaruhinya, seperti pelayanan kesehatan, status reproduksi, sosial ekonomi dan demografi. Tujuan penelitian adalah menganalisis secara spasial disparitas an- 
tara faktor intermediet dengan kematian maternal, menganalisis hubungan antara faktor intermediet dengan kematian maternal, menganalisis pengaruh faktor intermediet terhadap kematian maternal, dan memberikan rekomendasi terhadap masalah kesehatan maternal di Indonesia.

\section{BAHAN DAN METODE}

Penelitian ini merupakan penelitian noneksperimental mengunakan desain studi ekologi (studi agrerat). Unit analisis (sampel) dalam penelitian adalah populasi, yaitu seluruh kabupaten/ kota di Indonesia yang berjumlah 494 Kabupaten/ Kota.

Penelitian ini menggunakan data sekunder terdiri dari variabel terikat, yaitu proporsi kematian maternal yang dihitung dari jumlah kematian maternal selama proses kehamilan, persalinan dan nifas kecuali karena kecelakaan atau trauma dalam satu tahun dibagi dengan jumlah kelahiran. Sedangkan, variabel bebas terdiri dari cakupan kunjungan kehamilan pertama (K1), cakupan kunjungan kehamilan keempat (K4), cakupan persalinan oleh tenaga kesehatan (PN), cakupan kunjungan nifas $(\mathrm{KF})$, rata-rata jumlah anak, rata-rata lama sekolah wanita usia subur, tingkat kemiskinan, dan kepadatan penduduk. Data diperoleh dari Kementerian Kesehatan dan Badan Pusat Statistik (BPS). Data yang digunakan, yaitu selama kurun waktu satu tahun dari bulan Januari-Desember tahun 2013.

Analisis penelitian menggunakan analisis spasial, analisis bivariat, dan analisis multivariat. Sebelum dilakukan analisis spasial, setiap variabel dikelompokan berdasarkan nilai terendah dan tertinggi dengan menggunakan Receiver Operating Characteristic (ROC). ROC berupa kurva yang dibuat berdasarkan perhitungan confusion matrix antara False Positive Rate (FPR) dengan True Positive Rate (TPR) yang membagi data berdasarkan titik potong (cut of point). ${ }^{16,17}$ Dalam penelitian ini, pengelompokan data menggunakan ROC menjadi dua, yaitu tinggi (>titik potong),dan rendah ( $\leq$ titik potong). Analisis spasial menggunakan teknik overlay antara data angka kematian ibu dengan faktor intermediet. Overlay data menggunakan program STAT planet. Analisis bivariat menggunakan chi-square dan analisis multivariat menggunakan regresi logistik berganda.

\section{HASIL}

Hasil pengolahan data dengan ROC dan STAT Planet menunjukan banyak kabupaten/kota

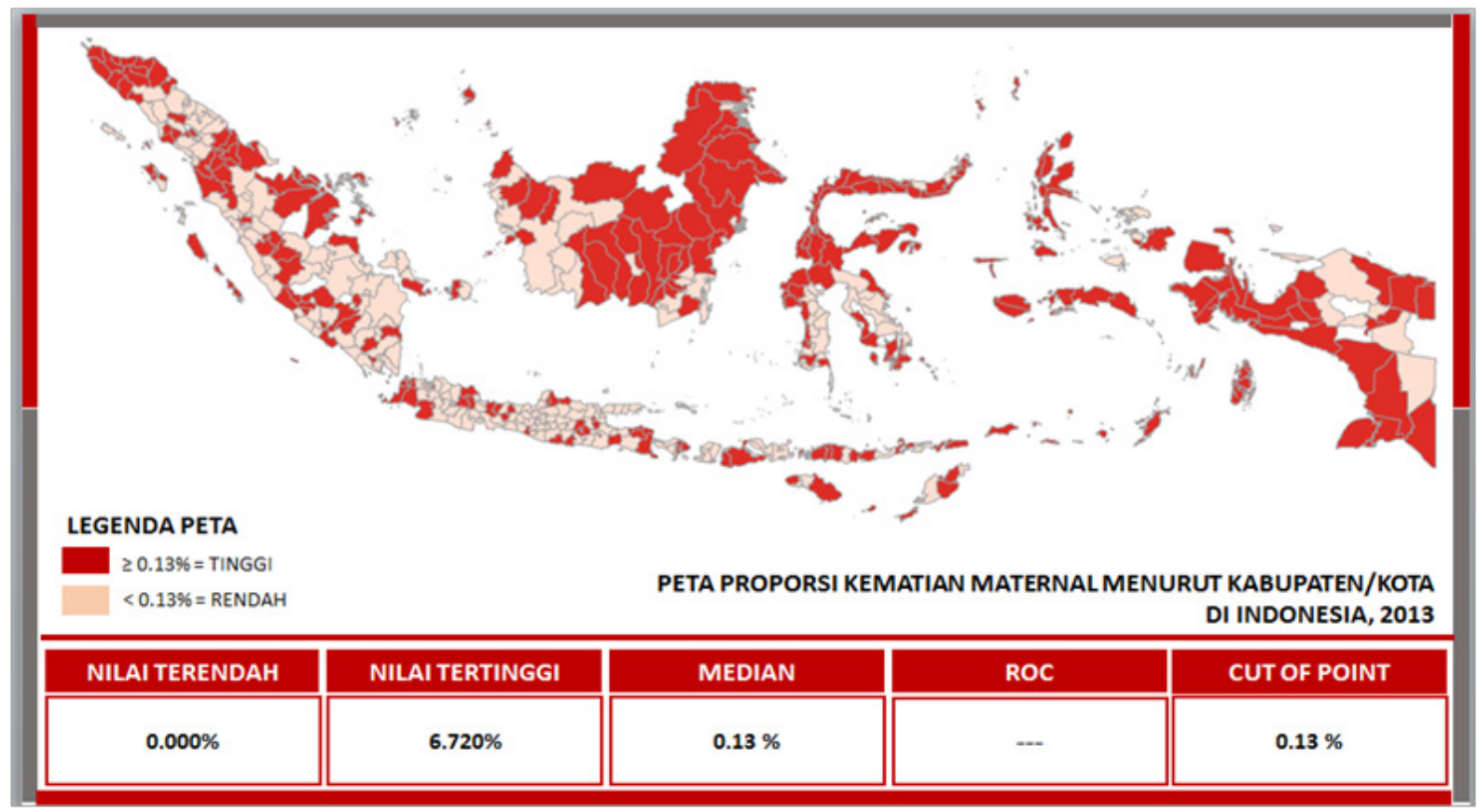

Gambar 1. Analisis Spasial Disparitas Kematian Maternal menurut Kabupaten/Kota di Indonesia 
di Indonesia yang masuk ke dalam kategori tinggi yaitu 52,4\% dari 494 kabupaten/kota yang menjadi unit analisis. Selain itu, terjadi disparitas kematian maternal antar kabupaten/kota di Indonesia. Hal ini dapat terlihat dari sebaran data, terdapat 90\% kabupaten/kota di kawasan Indonesia Timur masuk kategori tinggi (Gambar 1).

Hasil uji bivariat antara kematian maternal dengan variabel intermediet menunjukan enam dari delapan variabel intermediet menunjukan hubungan signifikan terhadap kematian maternal. Enam variabel tersebut adalah cakupan kunjungan kehamilan pertama (K1), cakupan kunjungan kehamilan keempat (K4), cakupan persalinan oleh tenaga kesehatan (PN), cakupan kunjungan nifas $(\mathrm{KF})$, rata-rata lama sekolah wanita usia subur, dan kepadatan penduduk, sedangkan yang tidak memiliki hubungan adalah rata-rata jumlah anak dan kemiskinan (Tabel 1).

Cakupan kunjungan kehamilan pertama (K1) menunjukkan $59,7 \%$ dari total kabupaten/ kota yang cakupan kunjungan kehamilan pertama (K1) rendah memiliki angka kematian maternal tinggi. Sedangkan $57,3 \%$ dari total kabupaten/ kota yang memiliki cakupan kunjungan kehamilan pertama (K1) tinggi memiliki angka kematian maternal rendah. Nilai $\mathrm{p} \leq 0.001$ (berhubungan signifikan).

Cakupan kunjungan kehamilan keempat (K4) menunjukkan $62,1 \%$ dari total kabupaten/ kota yang cakupan kunjungan kehamilan keempat (K4) rendah memiliki angka kematian maternal tinggi. Sedangkan $63,8 \%$ dari total kabupaten/ kota yang memiliki cakupan kunjugan kehamilan keempat (K4) tinggi memiliki angka kematian maternal rendah. Nilai $\mathrm{p} \leq 0.001$ (berhubungan signifikan).

Cakupan persalinan oleh tenaga kesehatan (PN) menunjukkan $64,9 \%$ dari total kabupaten/ kota yang cakupan persalinan oleh tenaga kesehatan $(\mathrm{PN})$ rendah memiliki angka kematian maternal tinggi. Sedangkan $62 \%$ dari total kabupaten/kota

Tabel 1. Uji Bivariat Kematian Maternal dengan Faktor Intermediet

\begin{tabular}{|c|c|c|c|}
\hline \multirow[b]{2}{*}{ Variabel } & \multicolumn{2}{|c|}{ Proporsi Kematian Maternal } & \multirow[b]{2}{*}{$\begin{array}{c}p \\
\text { OR }(95 \% C I)\end{array}$} \\
\hline & $\begin{array}{c}\text { Tinggi } \\
\text { n(\%) }\end{array}$ & $\begin{array}{c}\text { Rendah } \\
\text { n(\%) }\end{array}$ & \\
\hline \multicolumn{4}{|c|}{ Cakupan kunjungan kehamilan pertama (K1) } \\
\hline Rendah & $169(59.7)$ & $114(40.3)$ & 0.0 \\
\hline Tinggi & $90(42.7)$ & $121(57.3)$ & $1.993(1.388-2.862)$ \\
\hline \multicolumn{4}{|c|}{ Cakupan kunjungan kehamilan keempat (K4) } \\
\hline Rendah & $192(62.1)$ & $117(37.9)$ & 0.0 \\
\hline Tinggi & $67(36.2)$ & $118(63.8)$ & $2.890(1.981-42.17)$ \\
\hline \multicolumn{4}{|c|}{ Cakupan persalinan oleh tenaga kesehatan (PN) } \\
\hline Rendah & $172(64.9)$ & $93(35.1)$ & 0.0 \\
\hline Tinggi & $87(38.0)$ & $142(62.0)$ & $3.019(2.091-4.358)$ \\
\hline \multicolumn{4}{|l|}{ Cakupan kunjungan nifas (KF) } \\
\hline Rendah & $186(61.6)$ & $117(38.6)$ & 0.0 \\
\hline Tinggi & $73(38.2)$ & $118(61.8)$ & $2.570(1.771-3.729)$ \\
\hline \multicolumn{4}{|l|}{ Rata-rata jumlah anak } \\
\hline Tinggi & $185(57.3)$ & $138(42.7)$ & 0.04 \\
\hline Rendah & $74(43.3)$ & $97(56.7)$ & $1.757(1.209-2.555)$ \\
\hline \multicolumn{4}{|c|}{ Rata-rata lama sekolah wanita usia subur } \\
\hline Rendah & $194(58.6)$ & $137(41.4)$ & 0.0 \\
\hline Tinggi & $65(39.9)$ & $98(60.1)$ & $2.135(1.457-3.129)$ \\
\hline \multicolumn{4}{|l|}{ Tingkat kemiskinan } \\
\hline Tinggi & $175(55.2)$ & $142(44.8)$ & 0.119 \\
\hline Rendah & $84(47.5)$ & $93(52.5)$ & $1.364(0.994-1.973)$ \\
\hline \multicolumn{4}{|l|}{ Kepadatan penduduk } \\
\hline Rendah & $48(28.7)$ & $119(71.3)$ & 0.0 \\
\hline Tinggi & $211(64.5)$ & $116(35.5)$ & $0.222(0.148-0.332)$ \\
\hline
\end{tabular}


Tabel 2. Uji Multivariat Kematian Maternal dengan Faktor Intermediet

\begin{tabular}{lcccccc}
\hline \multicolumn{1}{c}{ Variabel } & \multirow{2}{*}{ B } & \multirow{2}{*}{ Wald } & Sig. & OR & \multicolumn{2}{c}{ CI 95\% } \\
\cline { 5 - 7 } & & & & Lower & Upper \\
\hline Cakupan kunjungan kehamilan pertama (K1) & $-0,226$ & 0,273 & 0,408 & 0,798 & 0,467 & 1,363 \\
Cakupan kunjungan kehamilan keempat (K4) & 0,520 & 0,293 & 0,076 & 1,682 & 0,947 & 2,988 \\
Cakupan persalinan olehtenaga kesehatan (PN) & 0,583 & 0,299 & 0,052 & 1,791 & 0,996 & 3,220 \\
Cakupan kunjungan nifas (KF) & 0,109 & 0,298 & 0,716 & 1,115 & 0,621 & 2,001 \\
Rata-rata jumlah anak & 0,040 & 0,232 & 0,862 & 1,041 & 0,661 & 1,640 \\
Rata-rata lama sekolah wanita usia subur & 0,153 & 0,238 & 0,521 & 1,165 & 0,731 & 1,857 \\
Kemiskinan & 0,072 & 0,216 & 0,738 & 1,075 & 0,704 & 1,642 \\
Kepadatan penduduk & $-1,176$ & 0,253 & 0,000 & 0,309 & 0,188 & 0,506 \\
\hline
\end{tabular}

yang memiliki cakupan persalinan oleh tenaga kesehatan (PN) tinggi memiliki angka kematian maternal rendah. Nilai $\mathrm{p} \leq 0.001$ (berhubungan signifikan).

Cakupan kunjungan nifas (KF) menunjukkan $61,4 \%$ dari total kabupaten/kota yang cakupan kunjungan nifas (KF) rendah memiliki angka kematian maternal tinggi. Sedangkan $61,8 \%$ dari total kabupaten/kota yang cakupan kunjungan nifas (KF) tinggi memiliki angka kematian maternal rendah. Nilai $\mathrm{p} \leq 0.001$ (berhubungan signifikan).

Rata-rata jumlah anak menunjukkan 57,3\% dari total kabupaten/kota yang rata-rata jumlah anak tinggi memiliki angka kematian maternal tinggi. Sedangkan 56,7\% dari total kabupaten/kota yang rata-rata jumlah anak rendah memiliki angka kematian maternal rendah. Nilai $\mathrm{p}>0.001$ (tidak berhubungan).

Rata-rata lama sekolah wanita usia subur menunjukkan $58,6 \%$ dari total kabupaten/kota yang rata-rata lama sekolah wanita usia subur rendah memiliki angka kematian maternal tinggi. Sedangkan $60,1 \%$ dari total kabupaten/kota yang rata-rata lama sekolah wanita usia subur tinggi memiliki angka kematian maternal rendah. Nilai $\mathrm{p} \leq 0.001$ (berhubungan signifikan).

Kemiskinan menunjukan $55,2 \%$ dari total kabupaten/kota yang angka kemiskinannya tinggi memiliki angka kematian maternal tinggi. Sedangkan $52,5 \%$ dari total kabupaten/kota yang angka kemiskinannya rendah memiliki angka kematian meternal rendah. Nilai $\mathrm{p}>0.001$ (tidak berhubungan).

Kepadatan penduduk menunjukkan $28,7 \%$ dari total kabupaten/kota yang kepadatan penduduknya tinggi memiliki angka kematian maternal tinggi. Sedangkan 35,5\% dari total kabupaten/ kota yang kepadatan penduduknya rendah memiliki angka kematian maternal rendah. Nilai $p \leq 0.001$ (berhubungan signifikan).

Hasil uji multivariat Tabel 2 menunjukkan nilai Odd Ratio (OR) variabel cakupan kunjungan kehamilan pertama (K1) sebesar 0.798 dengan nilai $\beta(-0.226)$. Hal ini menunjukkan bahwa probabilitas terbesar terjadinya kematian maternal tinggi berada di kabupaten/kota yang memiliki cakupan kunjungan kehamilan pertama (K1) tinggi. Nilai OR variabel cakupan kunjungan kehamilan keempat (K4) sebesar 1.682 dengan nilai $\beta$ (1.682). Hal ini menunjukkan bahwa probabilitas terbesar terjadinya kematian maternal tinggi berada di kabupaten/kota yang memiliki cakupan kunjungan kehamilan keempat (K4) rendah.

Nilai OR variabel cakupan persalinan oleh tenaga kesehatan $(\mathrm{PN})$ sebesar 1.791 dengan nilai $\beta$ (0.583). Hal ini menunjukkan bahwa probabilitas terbesar terjadinya kematian maternal tinggi berada di kabupaten/kota yang memiliki cakupan persalinan oleh tenaga kesehatan (PN) rendah. Nilai OR variabel cakupan kunjungan nifas (KF) sebesar 1.115 dengan nilai $\beta$ (0.109). Hal ini menunjukkan bahwa probabilitas terbesar terjadinya kematian maternal tinggi berada di kabupaten/kota yang memiliki cakupan kunjungan nifas (KF) rendah.

Nilai OR variabel rata-rata jumlah anak sebesar 1.041 dengan nilai $\beta(0.040)$. Hal ini menunjukkan bahwa probabilitas terbesar terjadinya kematian maternal tinggi berada di kabupaten/kota yang memiliki rata-rata jumlah anaktinggi. Nilai OR variabel cakupan rata-rata lama sekolah wanita usia subur sebesar 1.165 dengan nilai $\beta(0.153)$. Hal ini menunjukkan bahwa probabilitas terbesar terjadinya kematian maternal tinggi berada di ka- 
bupaten/kota yang memiliki rata-rata lama sekolah wanita usia subur rendah.

Nilai OR variabel kemiskinan sebesar 1.075 dengan nilai $\beta$ (0.072). Hal ini menunjukkan bahwa probabilitas terbesar terjadinya kematian maternal tinggi berada di kabupaten/kota yang memiliki kemiskinan tinggi. Nilai $O R$ variabel kepadatan penduduk sebesar 0.309 dengan nilai $\beta$ (-1.176). Hal ini menunjukkan bahwa probabilitas terbesar terjadinya kematian maternal tinggi berada di kabupaten/kota yang memiliki kepadatan penduduk rendah.

\section{PEMBAHASAN}

Persoalan disparitas menjadi masalah utama dalam kesehatan maternal di Indonesia. Tingginya kematian maternal di sebagian besar kabupaten/ kota di Kawasan Indonesia Timur merupakan persoalan yang harus mendapatkan perhatian khusus dari pemerintah. Model pembangunan yang berorientasi dan terpusat di Pulau Jawa dan Pulau Sumatera telah menimbulkan dampak buruk terhadap capaian kesehatan maternal. Dimana proporsi kematian maternal tertinggi terjadi di kawasan tersebut terutama di Papua, Maluku dan Nusa Tenggara.

Masalah utamanya adalah persoalan akses kesehatan maternal yang buruk di sebagian besar kabupaten/kota di Kawasan Timur Indonesia. Mulai dari rendahnya cakupan kunjungan kehamilan pertama (K1), cakupan kunjungan kehamilan keempat (K4), cakupan persalinan oleh tenaga kesehatan (PN), dan cakupan kunjungan nifas (KF) memberikan dampak terhadap tingginya kematian maternal di Kawasan Timur Indonesia.

Studi yang dilakukan oleh Rothman menunjukkan lebih dari seperempat kematian disebabkan oleh penyebab tidak langsung, salah satunya pelayanan kesehatan. Pelayanan kesehatan terhadap maternal berupa kunjungan pemeriksaaan kehamilan (K1 dan K4), persalinan oleh tenaga kesehatan (PN) dan kunjungan pada masa nifas (KF) seharusnya dapat dilakukan untuk mengurangi kematian ibu. ${ }^{18}$ Sehingga melakukan intervensi terhadap pelayanan kesehatan maternal menjadi penting untuk mengatasi risiko tingginya kematian maternal.

Adanya kontrol kehamilan yang baik disertai pencatatan yang baik dapat mengurangi faktor risiko penyebab kematian pada ibu hamil seperti hipertensi. Namun, seringkali pelayanan tersebut tidak berkesinambungan. Perlu memberikan intervensi intensif dalam meningkatkan kualitas dan akses pelayanan ibu hamil dan melahirkan sesuai dengan tahapan yang dianjurkan secara kesehatan. ${ }^{19,20}$

Penelitian Sulistiyowati dkk menemukan bahwa determinan dekat penyebab kematian ibu, komplikasi kehamilan dan persalinan,serta determinan jauh berupa pemerikasaan antenatal yang tidak baik menimbulkan risiko terhadap kematian maternal. ${ }^{21}$ Penyulit persalinan yang tidak segera dirujuk ke fasilitas pelayanan kesehatan merupakan salah satu penyebab tingginya angka kematian maternal. ${ }^{22,23}$ Hasil penelitian Nurfatimah menunjukkan risiko kematian maternal bagi ibu hamil yang mengalami keterlambatan dalam mencapai fasilitas kesehatan 3,1 kali lebih besar dibandingkan ibu yang tidak mengalami keterlambatan dan 6,5 kali berisiko ketika terlambat mendapatkan pertolongan medis. ${ }^{24}$

Selain faktor layanan kesehatan maternal, faktor tidak langsung lainnya yang menyebabkan risiko kematian maternal adalah jumlah anak, pendidikan, kemiskinan dan kepadatan penduduk. Ibu hamil yang memiliki jumlah anak lebih banyak dan jarak kehamilan yang dekat cenderung rentan dengan masalah reproduksi. Kerentanan masalah reproduksi seperti pendarahan dan repture uteri berakibat kepada risiko kematian maternal. WHO tahun 2011 mengatakan bahwa negara yang memiliki tingkat fertilitas tinggi juga memiliki angka kematian maternal yang tinggi. ${ }^{25}$

Masalah kemiskinan juga menyebabkan risiko kematian maternal, walaupun dalam penelitian ini tidak ditemukan hubungan yang signifikan antara kematian maternal dengan kemiskinan, tetapi probabilitas kabupaten/kota yang tingkat kemiskinannya tinggi memiliki angka kematian maternal yang juga tinggi. Hal ini tentu menjadi perhatian khusus karena persoalan kemiskinan merupakan persoalan utama saat ini dan pemerintah sangat fokus untuk mengatasinya. Namun, persoalannya adalah banyak program kemiskinan yang tidak terintegrasi dengan kesehatan maternal sehinggat intervensi program hanya bersifat parsial. Ketika program tidak terintegrasi akibatnya akses kesehatan maternal bagi kelompok miskin menjadi rendah. ${ }^{26,27}$ 
Selain kemiskinan, faktor rendahnya pendidikan pada wanita usia subur juga berdampak terhadap risiko kematian maternal. Hal ini ditemukan dalam penelitian ini. Kabupaten/kota yang tingkat pendidikan wanita usia suburnya rendah memiliki risiko kematian maternal yang tinggi. Ibu hamil yang memiliki pendidikan rendah terlebih buta huruf cenderung tidak menggunakan fasilitas dalam pelayanan kesehatan pada saat kehamilan. ${ }^{28}$ Penelitian yang dilakukan Syafiq menunjukkan hubungan antara pendidikan dan kematian ibu, terdapat korelasi negatif (hubungan terbalik) antara pendidikan dengan angka kematian maternal di Indonesia. Semakin tinggi pendidikan semakin rendah risiko kematian maternal. ${ }^{29}$

Faktor kepadatan penduduk juga mempengaruhi risiko kematian maternal. Hasil penelitian ini menemukan bahwa kabupaten/kota dengan tingkat kepadatan penduduk rendah memiliki risiko kematian maternal tinggi. Kondisi ini terjadi karena kondisi geografis daerah. Sebagian besar kabupaten/kota di kawasan Indonesia Timur memiliki daerah yang luas tapi minim penduduk. Konsekwensinya adalah fasilitas kesehatan minim dan jarak tempuhnya jauh. Jarak tersebut menyebabkan layanan kesehatan maternal sulit diakses oleh ibu hamil sehingga risiko kematian menjadi tinggi. ${ }^{30}$

\section{KESIMPULAN DAN SARAN}

Dari hasil analisis dapat disimpulkan bahwa terjadi disparitas kematian maternal antar kabupaten/kota di Indonesia. Kabupaten/kota yang berada di kawasan Indonesia Timur merupakan daerah yang memiliki kematian maternal tinggi, seperti kabupaten/kota di Propinsi Papua, Papua Barat, Maluku, Maluku Utara, dan Nusa Tenggara Timur. Dari delapan variabel faktor intermediet yang mempengaruhi kematian maternal, terdapat enam variabel yang mempengaruhi yaitu cakupan kunjungan kehamilan pertama (K1), cakupan kunjungan kehamilan keempat (K4), cakupan persalinan oleh tenaga kesehatan (PN), cakupan kunjungan nifas (KF), rata-rata lama sekolah wanita usia subur, dan kepadatan penduduk, sedangkan yang tidak memiliki hubungan adalah rata-rata jumlah anak dan kemiskinan.

Berdasarkan uji multivariat risiko kematian maternal terjadi pada kabupaten/kota dengan cakupan kunjungan kehamilan keempat (K4) rendah, cakupan persalinan oleh tenaga kesehatan (PN) rendah, cakupan kunjungan nifas (KF) rendah, ratarata jumlah anak tinggi, rata-rata lama sekolah wanita usia subur rendah, dan kemiskinan tinggi. Dari temuan penelitian disarankan bagi pemerintah untuk memberikan prioritas intervensi program kesehatan maternal pada kabupaten/ kota yang tingkat kematian maternal tinggi yang sebarannya banyak di kawasan Indonesia Timur. Prioritas intervensi diarahkan pada program peningkatan akses dan kualitas pelayanan kesehatan maternal mulai dari kunjungan kehamilan pertama (K1), kunjungan kehamilan keempat (K4), persalinan oleh tenaga kesehatan (PN), dan kunjungan nifas (KF).

Selain itu, intervensi di luar pelayanan kesehatan maternal juga penting seperti integrasi antara program kemiskinan dengan program kesehatan maternal, peningkatan pendidikan dan pengetahuan kesehatan maternal terhadap wanita usia produktif, dan sosialisasi terhadap program Keluarga Berencana (KB) agar menekan risiko terjadinya masalah kesehatan reproduksi terhadap ibu hamil dan melahirkan.

\section{DAFTAR PUSTAKA}

1. World Health Organization. World Health Statistic: Monitoring Health for the SDGs (Sustainable Development Goals). Geneva: WHO; 2017.

2. Badan Perencanaan Pembangunan Nasional. Laporan Pencapaian MDGs di Indonesia 2013. Jakarta: Bappenas; 2014.

3. Badan Pusat Statistik. Potret Awal Tujuan Pembangunan Berkelanjutan (Sustainable Development Goals) di Indonesia. Jakarta: Bappenas; 2017.

4. Astuti, KS., Aziz AM., and Insy Farisa DA. Maternal Mortality Risk Factors in dr. Hasan Sadikin General Hospital, Bandung in 20092013. International Journal of Integrated Health Sciences, Vol. 5, No 2 September 2017.

5. Rahman A, Nisha MK, Begum T, Ahmed S, Alam N, Anwar I. Trends, Determinants, and Inequities of 4+ ANC Utilisation in Bangladesh. J Health Popul Nutr. 36(1):2. 2017.

6. Bobo FT, Yesuf EA, and Woldie M. Inequities in Utilization of Reproductive and Maternal Health Services in Ethopia. Int J Equity 
Health, Jun 19;16(1):105. 2017.

7. Tarekegn SM, Liebermen LS, and Giedraitis V. Determinants of Maternal Health Service Utilization in Ethopia. Analysis of the 2011 Ethopian Demographic and Health Survey. BMC Pregnancy Childbirth. 2014;14:161.

8. Badan Pusat Statistik. Potret Awal Tujuan Pembangunan Berkelanjutan (Sustainable Development Goals) di Indonesia. Jakarta: Bappenas; 2017.

9. Prasetyo, Budi, et.al. Maternal Mortality Audit based on District Maternal Health Performance in East Java Province, Indonesia. Bali Medical (Bali Med J). 2018;7(1): 61-67.

10. Berhan Y, Berhan A. Antenatal Care as A Means of Increasing Birth in The Health Facility and Reducing Maternal Mortality: A Systemic Review. Ethiop J Health Science. 2014; September, Special Issue.

11. Ikhtiar M., Hadju Veni, Thaha Ridwan and M. Syafar. Study on Health Social Determinants as Cause of Maternal Mortality in Gowa District South Sulawesi, 2013. International Journal of Scientific and Research Publications. 2014;4(6).

12. Nababan, Y.H., et.all. Trends and Inequities in Use Maternal Health Care Service in Indonesia, 1986-2012. International Journal of Women's Health. 2018; 10.

13. Anwar I, Nababan HY, Mostari S, Rahman A, and Khan JA. Trends and Inequities in Use of Maternal Health Care Services in Bangladesh, 1911-2011. PLoS One. 2015;10(3).

14. Black RE, Laxminarayan R, Marleen T, Walker N. Disease Control Priorities Third Edition: Reproductive, Meternal, Newborn, Child Health. Washington DC: World Bank; 2016.

15. Mustapha AK, Yusuf MA, Abdulkarim GM, and Muhammad C. Spatial and Temporal Variations of Maternal Deaths in Borno State of Nigeria: Institutional Based Study. International Journal of Tropical Disease and Health. 2017;27(1): 1-14.

16. Hoo, ZH., Candlish, J. and Teare, M.D. What is an ROC Curve? Emergency Medicine Journal. 2017.

17. Krupinski, A.K. Receiver Operating Characteristic (ROC) Analysis. Frontline Learning Research. 2017;5(3).
18. Rothman KJ et all. Modern Epidemiology: Third Edition. USA; 2008.

19. Saputra W, Nurrizka R. Strategi Menurunkan Angka Kematian Ibu dan Angka Kematian Anak di Indonesia. Depok: Prakarsa; 2014

20. Say L, Chou D, Gemmill A, Tuncalp O, Moller AB, Daniels J, Gulmezoglu AM, Temmerman M, Alkema L. Global causes of maternal death: A WHO Systematic Analysis. Lancet Glob Health. 2014; Jun;2(6): e323-33. doi: 10.1016/S2214-109X (14)70227-X. Epub 2014 May 5.

21. Sulistiyowati, N, Puti Sari, H, dan Dwi Hapsari, T. Kesinambungan Pemanfaatan Pelayanan Kesehatan Maternal di Indonesia. Buletin Penelitian Kesehatan. 2017;45(3):177-186.

22. Mellisa B, Adrien L, Vanessa T, Antoinette $\mathrm{T}$ et all. Risk Factors for Maternal Death and Trends in Maternal Mortality in Low and Middle-Income Countries: a Prospective Longitudinal Cohort Analysis. BMC Reproductive Health. 2015;12 (Suppl 2): S5.

23. Aeni N. Faktor Risiko Kematian Ibu. Jurnal Kesehatan Masyarakat Nasional. 2013;7(10).

24. Nurfatimah. Determinan Penyulit Persalinan. Jurnal MKMI. September 2014; 160-165.

25. World Health Organization. the Prevention and Elimination of Disrespect and Abuse During Facility Based Childbirth: WHO; 2014.

26. Sparrow R, Suryahadi A, and Widyanti W. Social Health Insurance for the Poor: Targeting and Impact of Indonesia's Askeskin Programme. Soc Sci Med. 2013; 96:264-271.

27. Harimurti P, Pambudi E, Pigazzini A, and Tandon A. The Nuts and Bolts of Jamkesmas Indonesia's Government-Financed Health Coverage Program for the Poor and Near-Poor. Washington DC: World Bank. 2013. (UNICO Studies Series No. 8).

28. Ahmed S, Creanga AA, Gillespie DG, and Tsui AO. Economic Status, Education and Empowerment: Implications for Maternal Health Service Utilization in Developing Countries. PLoS One. 2010;5(6).

29. Syafiq A. Angka Kematian Ibu dan Pendidikan Perempuan di Indonesia: Tinjauan Ekologis Provinsial. Jakarta: (Disajikan Pada Konferensi Infid 2013 dengan tema "Pembanguanan Untuk Semua: MemperjuangkanKualitasPe- 
merintah, Hak Asasi Manusia dan Inklusi dalam Rencana Pembangunan Jangka Menengah 2015-2019” Hotel Royal Kuningan Jakarta 26 - 27 November 2013); 2013.

30. Meliala A, Hort K, and Trisnantoro L. Ad- dressing the Unequal Geographic Distribution of Specialist Doctors in Indonesia: The Role of the Private Sector and Effectiveness of Current Regulations. Soc Sci Med, 82:30-34. 2013. 